Canadian University Music Review

Canadian University Music Review

Revue de musique des universités canadiennes

\title{
Violet's Invention: A Piano Piece for Violet Archer in Her Seventy-Fifth Year
}

\section{Larry Austin}

Volume 16, numéro 1, 1995

Voices of Women: Essays in Honour of Violet Archer

Voix de femmes : mélanges offerts à Violet Archer

URI : https://id.erudit.org/iderudit/1014413ar

DOI : https://doi.org/10.7202/1014413ar

Aller au sommaire du numéro

Éditeur(s)

Canadian University Music Society / Société de musique des universités

canadiennes

ISSN

0710-0353 (imprimé)

2291-2436 (numérique)

Découvrir la revue

Citer ce document

Austin, L. (1995). Violet's Invention: A Piano Piece for Violet Archer in Her Seventy-Fifth Year. Canadian University Music Review / Revue de musique des universités canadiennes, 16(1), 7-13. https://doi.org/10.7202/1014413ar 


\title{
VIOLET'S INVENTION: A PIANO PIECE FOR VIOLET ARCHER IN HER SEVENTY-FIFTH YEAR
}

\author{
Larry Austin
}

During Violet Archer's tenure at the University of North Texas, Denton, from 1950 to 1952, I was her student in private composition and piano lessons. As my first real composition teacher, Violet was perfect. She enthusiastically encouraged and guided my efforts, from my Sonatina for violin and piano (1950) to my Concertino for flute, trumpet, and string orchestra (1952) four pieces later: five bit pieces in two years! Yes, she instilled in me, early on, a passion to invent, to explore, and to be creatively productive. What fluency and invention I have sustained through the years since then was first nurtured by her challenging model as a prolific and ingeniously inventive composer. This piano piece, Violet's Invention, is composed for her as a small token of thanks to and admiration for her in this, her seventy-fifth year. (Note: The premiere performance of Violet's Invention was presented on 7 March 1991, in Concert II of the Society of Composers, Inc., 1991 Region VI Conference, Adam Wodnicki, pianist, in Irons Recital Hall, University of Texas, Arlington, Texas.)

Violet's Invention is a canon whose pitches derive from anagrammatic extrapolations of the letters in Violet Archer's name. Form, rhythmic design and melodic/harmonic continuity were created through a "Violet Archer ordering" of virtually all of the metaphorically appropriate anagrams that can be made with the two words of her name, themselves metaphors for what I sense as the Apollonian and Dionysian sides of her nature and her music.

The indication "chromatics exclusive" means that all chromatic alterations affect only the immediate pitch; "col pedale" indicates the pianist's use of the sustaining pedal through the course of the piece to enhance the resonance and contrapuntal quality of the presto sections, contrasted with the quietly ringing sonorities of the subito adagio sections. Only the topmost pitch of the "tr" three-note clusters in the first part of the piece is to be trilled, a half-step higher.

Larry Austin

Denton, Texas

22 August 1988

C Larry Austin 1988 


\section{VIOLET'S INVENTION}

a piano piece for Violet Archer in her 75th year

Larry Austin (1988)
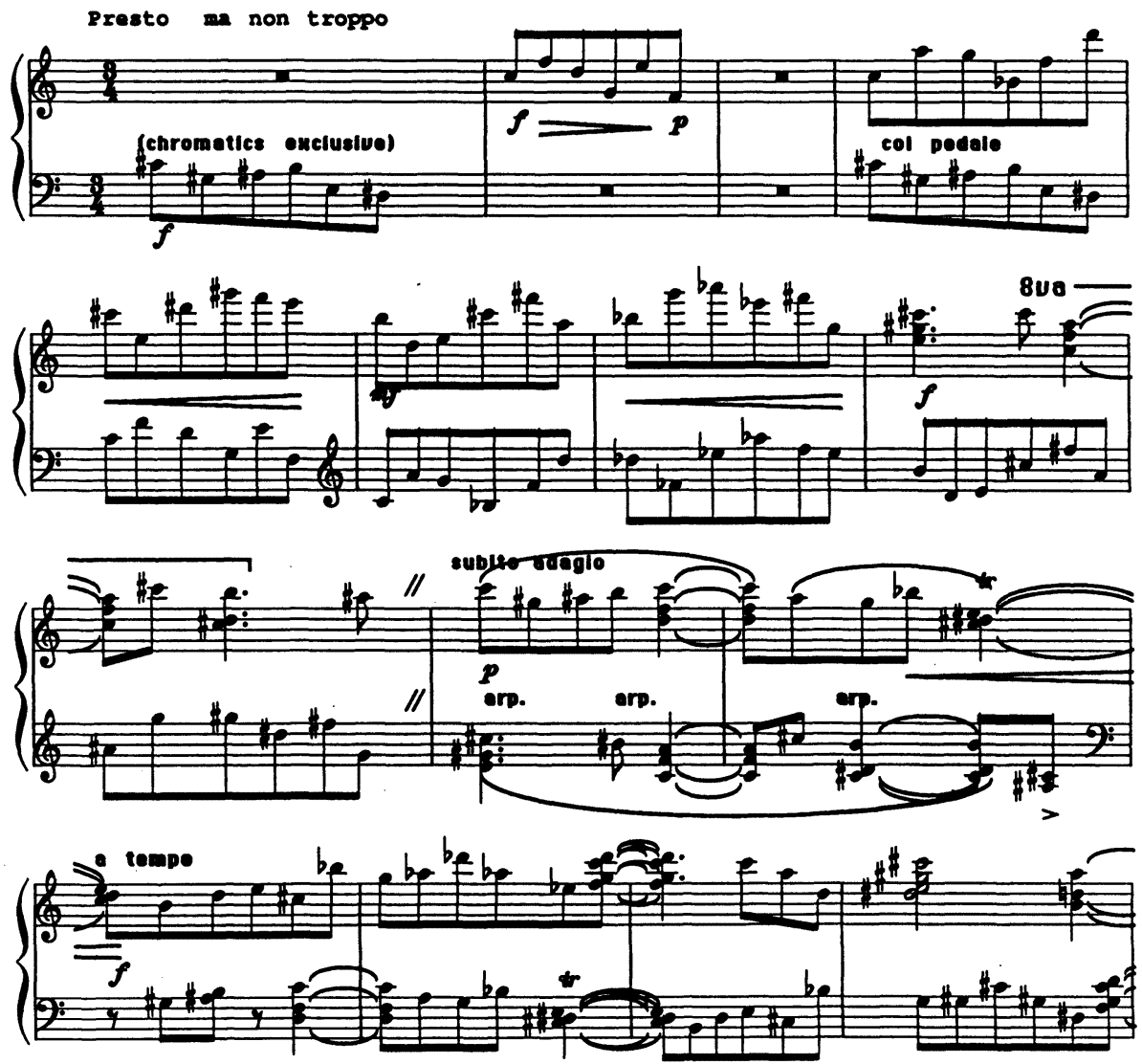

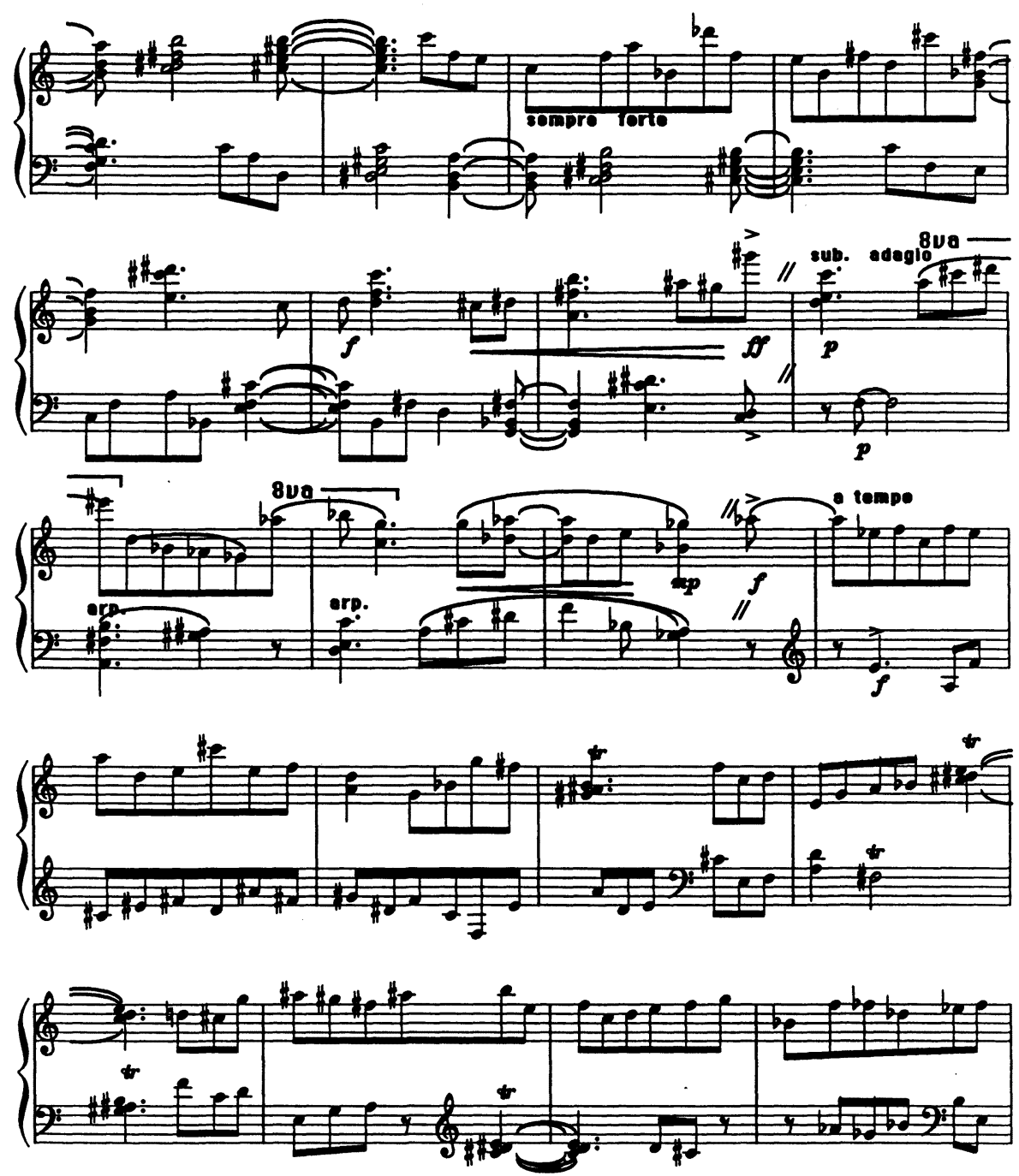

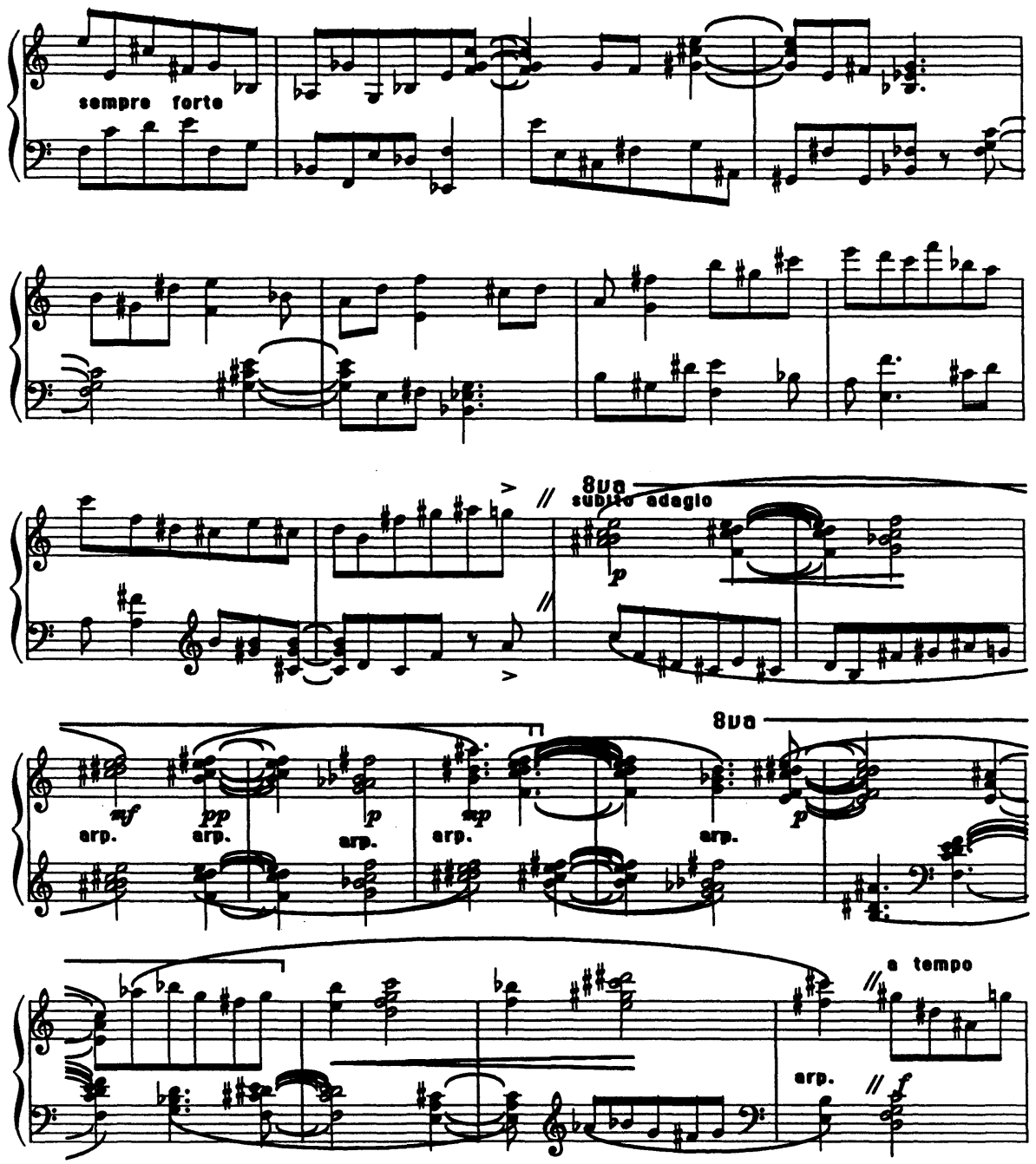

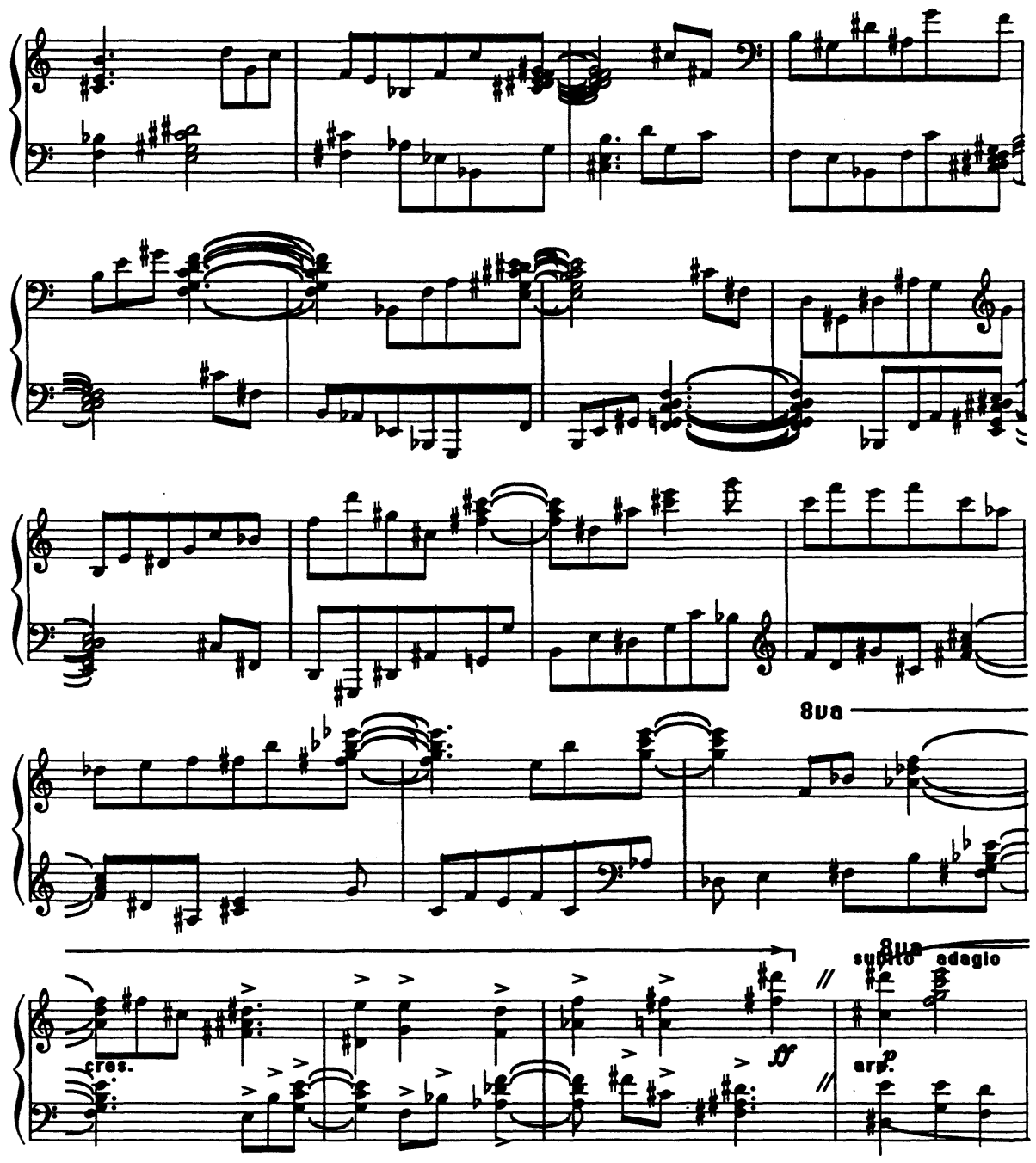

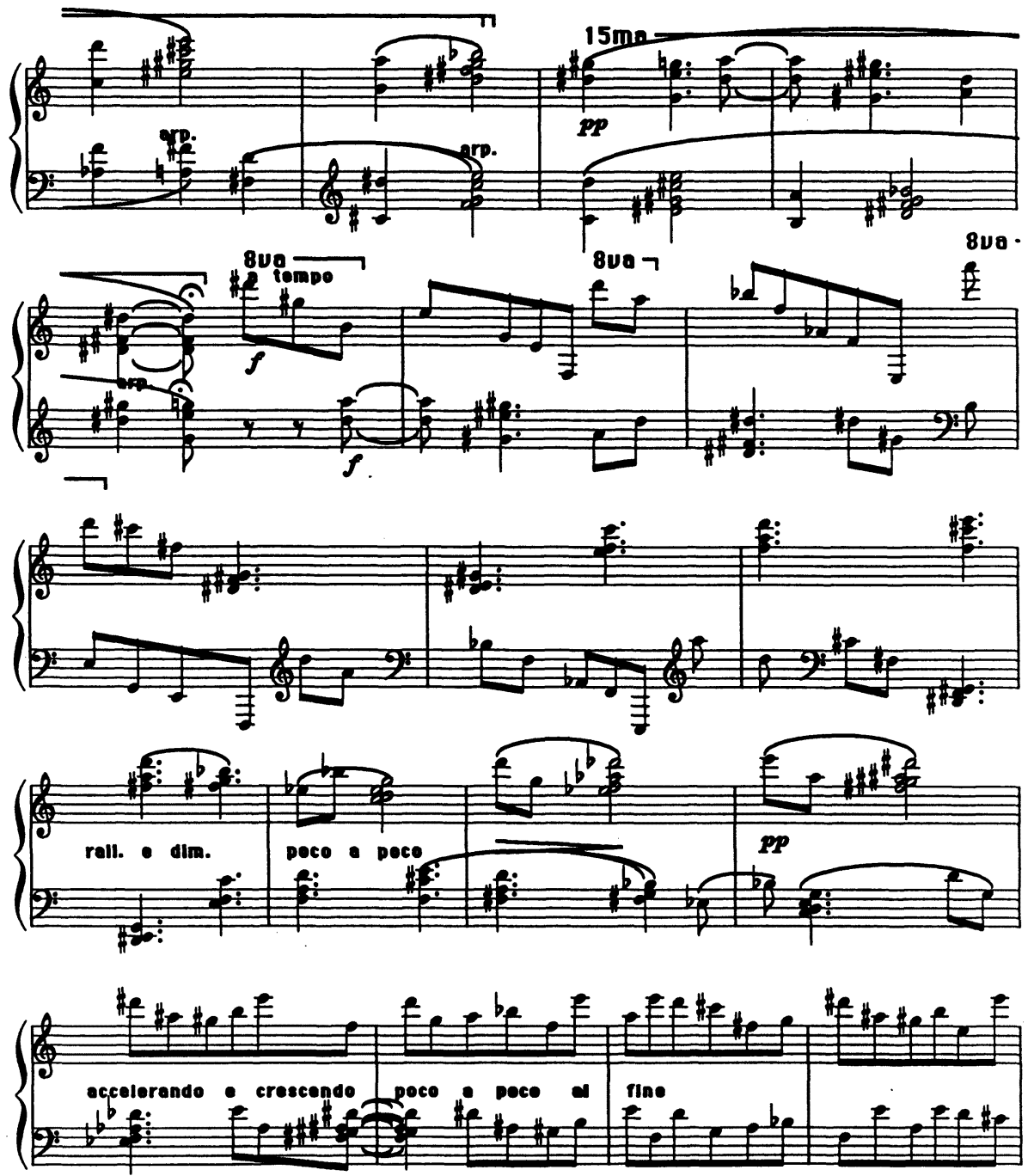

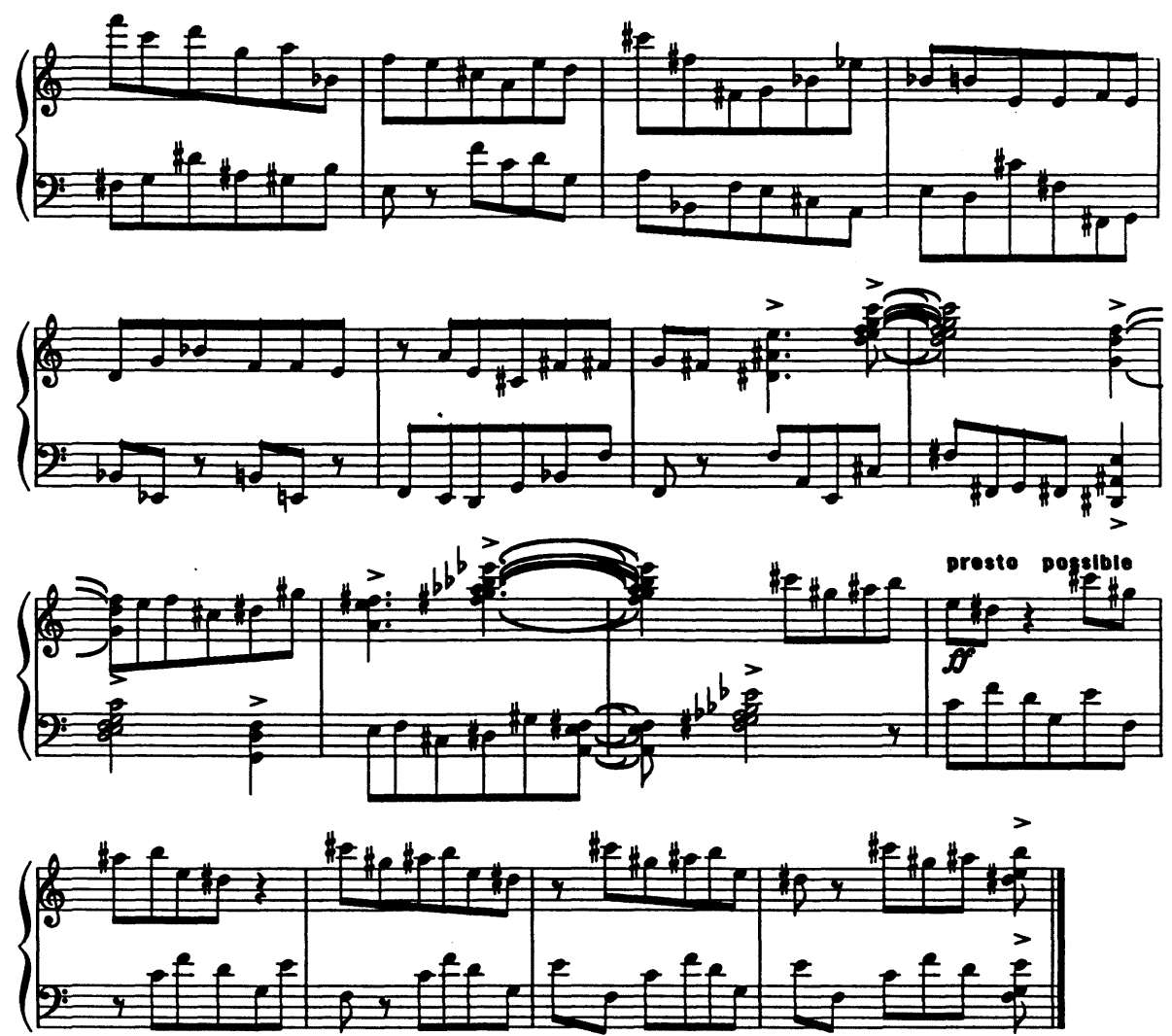